\title{
The Effects Of Customer Dissatisfaction On Switching Behavior In The Service Sector
}

Yoon C. Cho, KDI School of Public Policy and Management, Korea Juyeon Song, Georgia Institute of Technology, USA

\begin{abstract}
Customer acceptance in the online environment has been drastically changed due to the presence of the Internet. After adopting products, customers' willingness to adopt services in the online environment has received increased attention. This study explores how customers are willing to switch from offline to online services by examining i) the factors of dissatisfaction in the offline service environment; ii) how overall dissatisfaction affects regret and complaining behavior; and iii) how the level of regret and complaining behavior affects switching behavior. Proposed relationships are developed based on the theoretical background of satisfaction/dissatisfaction in the virtualized environment. By applying various statistical analyses, this study identifies managerial and theoretical implications and offers suggestions for the management of e-business customer relationships.
\end{abstract}

Keywords: Service; Virtualization; Dissatisfaction; Regret; Complaining Behavior; and Loyalty

\section{INTRODUCTION}

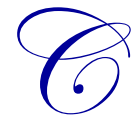

ustomers' behavior in the virtualized environment, known as Web-based, has changed due to technological development. Cho (2012) stated that most e-commerce innovations gradually absorb behavior as customers prove their worth beyond the initial trial phase. The term, "virtualized" environment has been used for both the online environment and the computer mediated environment (Hoffman and Novak 1996) interchangeably with the "telepresent" environment (Steuer 1992), where there is no physical manifestation (Peppard and Rylander 2005). The current growth of the successful application of "telepresence" in a number of different settings and different roles, suggests that the traditional economic activities of old are undergoing a profound transformation.

Previous studies (Figueiredo 2000) addressed the way in which customers adopt a product (i.e., tangible goods) in the telepresent environment by classifying product attributes that are differently judged online, but the way in which customers adopt the service (i.e., intangible goods) in the telepresent environment has been less investigated. Even though certain service industries such as auctions or the stock market have gained and advantages in the telepresent environment, such as $24 / 7$ accessibility, other service sectors (e.g., insurance) have relied relatively more on other communications tools, such as offline and telemarketing rather than online. A stock transaction or the management of bank account online was successfully adopted as the quality of those services is easily determined on the Web (Figueiredo, 2000), while parts of certain service sectors, such as insurance, were not widely adopted and have become relative newcomers in the virtualized environment. For example, customers often visit websites to acquire information about insurance though the inquiry does not lead to any actual purchase behavior. According to Ahn and Ki (2007), customers in the U.S. purchased their auto insurance via the internet only $2 \%$ of the time in 2005 , even though more than $50 \%$ of all customers who had recently shopped for auto insurance had visited an insurance company website (Insurance Research Council Survey, 2009).

Previous studies (Cho 2011, Cho, Im, Hiltz, and Fjermestad, 2001) have addressed customer satisfaction/dissatisfaction as clues to what managerial changes may have induced different and more desirable behaviors, raising the issue of customer loyalty myopia. Factors that cause dissatisfaction in the virtualized environment have been addressed by examining product categories, based on the fact that quality is not easily 
determined on the Web (Figueiredo, 2000). However, factors that affect dissatisfaction with service sectors online have been examined less often. Prior studies also addressed the effects of a virtualized environment, such as situational/environmental factors with retail format preferences (Gehrt, Ingram, and Howe 1991; Gehrt and Yan 2004; Palmer 1997). Based on these considerations, the purpose of this study is to investigate the effects of customers' willingness to "switch the channel," from offline to online, on the service sector by examining negative aspect such as dissatisfaction, regret, and complaining behavior. In particular, this study investigates the following issues: i) how do the proposed factors of the service sector affect dissatisfaction with contact person, core service, and/or institution; ii) how dissatisfaction with contact person, core service, and/or institution affects overall dissatisfaction; iii) how overall dissatisfaction affects regret; iv) how regret affects complaining behavior; and v) how complaining behavior affects switching behavior.

\section{LITERATURE REVIEW}

According to prior studies (Chen and Tan 2004; Zeithaml, Parasuraman and Berry 1985), service is marked by four unique characteristics: intangibility, inseparability of production and consumption, heterogeneity, and perishability. With the most distinctive point which is intangibility, services cannot be seen, felt, tasted, or touched in the same manner that goods can be sensed (Zeithaml et al., 1985). Services require confidence because customers cannot experience actual services at the moment of purchase. As with a virtualized environment, customers' use of the service sector has been moved from offline to an online environment, yet there are sectors in which customers are not willing to adopt or purchase services online. Customers' willingness to use online services has been explained as dependent upon the characteristics of products and services. Fiqueiredo (2000) claimed that products or services can be grouped into four spectra depending on the ability to judge the quality of a product: commodity products, quasi-commodity products, "look and feel goods" and "look and feel goods" with variable quality.

Service sectors requiring relationship marketing (Crosby and Stephens 1987) have relied on the roles of agents who are the primary contact persons and on whose advice buyers rely in finding a suitable policy. Keaveney (1995) stated that a review of the services and products literatures revealed a variety of potential, and sometimes conflicting, reasons that customers might switch services. Prior studies stated that customer switching behavior has been related to perceptions of quality in the banking industry (Rust and Zahorik 1993), overall dissatisfaction in the insurance industry (Crosby and Stephens 1987), and service encounter failures in retail stores (Kelley, Hoffman, and Davis 1993). Among the service sectors, the distribution of insurance (e.g., life insurance) seems to require a higher level of long-term relationship marketing (Crosby and Stephens 1987) to provide high credence service (Lynch and Mackay 1985). Customers' needs for follow-up services after the initial purchase (Johnston-O'Connor, O'Connor, Zultowski 1984) are increased to reduce dissatisfaction with policy changes (Crosby and Stephens 1987). Therefore, how businesses provide a maximized relationship online is the key to reducing customer dissatisfaction and changed usage within a virtualized environment.

Prior studies discussed reasons that customers might switch services (Keaveney 1995). A study by Keaveney (1995) stated that service quality (Bitner 1990), relationship quality (Crosby, Evans, and Cowles 1990; Crosby and Stephens 1987), and overall service satisfaction (Cronin and Taylor 1992) can improve customers' intentions to stay with a firm. This study examined determinants that affect the service sector online, particularly actors (Chiu and Shin, 2009) which affects customers' switching behavior from traditional to electronic channels (Gupta, Su, and Walter, 2004), by examining the negative sides of satisfaction. Consumer dissatisfaction, a state of cognitive or emotional discomfort caused by insufficient return relative to the resources invested (time, money, emotion, and so on) by the consumer at any stage in the relationship with the seller (Fornell \& Wernerfelt, 1987), has been the focus of much research in recent years (Yang, Tu, and Yang 2009). Dissatisfaction, explained by the expectancy disconfirmation model, states that key variables affecting the evaluation of product performance consistently include expectation and confirmation/disconfirmation (Yi, 1990). Yang et al. (2009) also posited that dissatisfaction might impel a firm to create better products and provide better services, and remains as a detriment for consumer innovation.

Previous studies addressed the negative sides of satisfaction by revealing the relationships between regret and complaining behavior (Cho 2011) in the virtualized environment. Dissatisfaction has been explained by the level of disconfirmation with the focus on uncertainty, such as the desirability of alternatives that are considered to 
be the basis for reasons that customers are dissatisfied and regretful (Oliver 1997). According to the Inman and Zeelenberg (2002), regret is the painful sensation of recognizing that "what is" compares unfavorably with "what might have been" (Sugden 1985, pp.77). Oliver (1997) stated that regret stems from a comparison to alternative outcomes that could have been likely or could have been foreseen, while not all alternative events are necessarily equally likely or foreseeable. Complaints, the next stage of regret are explained in the context of the expectancy disconfirmation model, the psychological dynamics of complaint handling (Oliver, 1997). According to Chan (1998), consumer complaints are good indicators of service quality because consumers who are satisfied with the insurer are probably less likely to file complaints. Chan (1998) also stated that the degree to which consumers may have unrealistic expectations also depends on how well the company agents explain the insurance policies to the consumers, which is also part of the service provided by the company.

Based on the consideration above, this study examines i) how the causes that affect customer dissatisfaction are classified by three categories; ii) how customer dissatisfaction that are classified by categories affect overall dissatisfaction; iii) how overall dissatisfaction affects regret; iv) how regret affects complaining behavior; and v) how complaining behavior affects switching behavior. This study measures those effects to investigate the willingness of customers to switch offline to online for a service sector, particularly the insurance industry. Further, this study analyzes service factors that are categorized according to the following aspects: the sales person factor, the client management factor, the product attractiveness factor, the pricing factor, the payment service factor, the ease of use factor, the brand image factor, and the product information factor in the traditional channel.

\section{HYPOTHESES DEVELOPMENT}

Prior researchers have investigated issues in services marketing widely. Zeithaml, Paramuraman, and Berry (1985) summarized studies on the characteristics of services as intangibility, heterogeneity, inseparability of production and consumption, and perishability. Among those characteristics, prior studies classified characteristics of services as intangibility as they cannot be seen, felt, tasted, or touched in the same manner in which goods can be sensed, and inseparability, as the producer and the seller are the same entity, making only direct distribution possible in most cases (Zeithaml, Paramuraman, and Berry 1985; Upah 1980). How those characteristics are applied in the virtualized environment has been addressed in other studies. Some businesses gain an advantage by addressing issues of intangibility in the virtualized environment, while other e-businesses are still used as information purpose only but not for the purpose of actual purchase. Mohammad, Fisher, Jaworski, and Cahill (2002) stated that the web can help make intangible services or experiences seem more tangible by providing cues, such as virtual tours and other advanced technologies.

Service quality, which is viewed as a critical component of customer perceptions of service and its consequences, such as satisfaction and behavioral intentions are explained by studies such as Durvasula, Lobo, Lysonski, and Mehta (2005). In considering the effects of causes and consequences, studies (e.g., Crosby and Stephens 1987) addressed relationship marketing as a recommended strategy to overcome service intangibility, particularly in the case of the insurance industry. By proposing the Relationship Effects Model (REM), a study by Crosby and Stephens (1987) addressed predictors of satisfaction, interaction, and communications variables, which pertain to the salience of information flow, a combined function of frequency and customer- perceived importance. The distribution of whole life insurance seems to suggest relationship marketing (Crosby and Stephens 1987), as it is usually sold by an agent who is the primary contact person and on whose advice buyers rely in finding a suitable policy (Crosby and Stephens 1987). When making the initial purchase, customers seldom consulted more than one agent or compared costs (Johnston-O'Connor, O'Connor, Zultowski 1984). After the sale, agents provided followup service, helping customers make policy changes in response to changing needs (Crosby and Stephens 1987). Based on this consideration, the model of dissatisfaction, regret, and complaining behavior in service sector was proposed (Figure 1). As show in Figure 1, this study posits how a virtualized environment, which is known for its high level of interactivity, switches customers' attitudes from offline in the case of the service sector. 


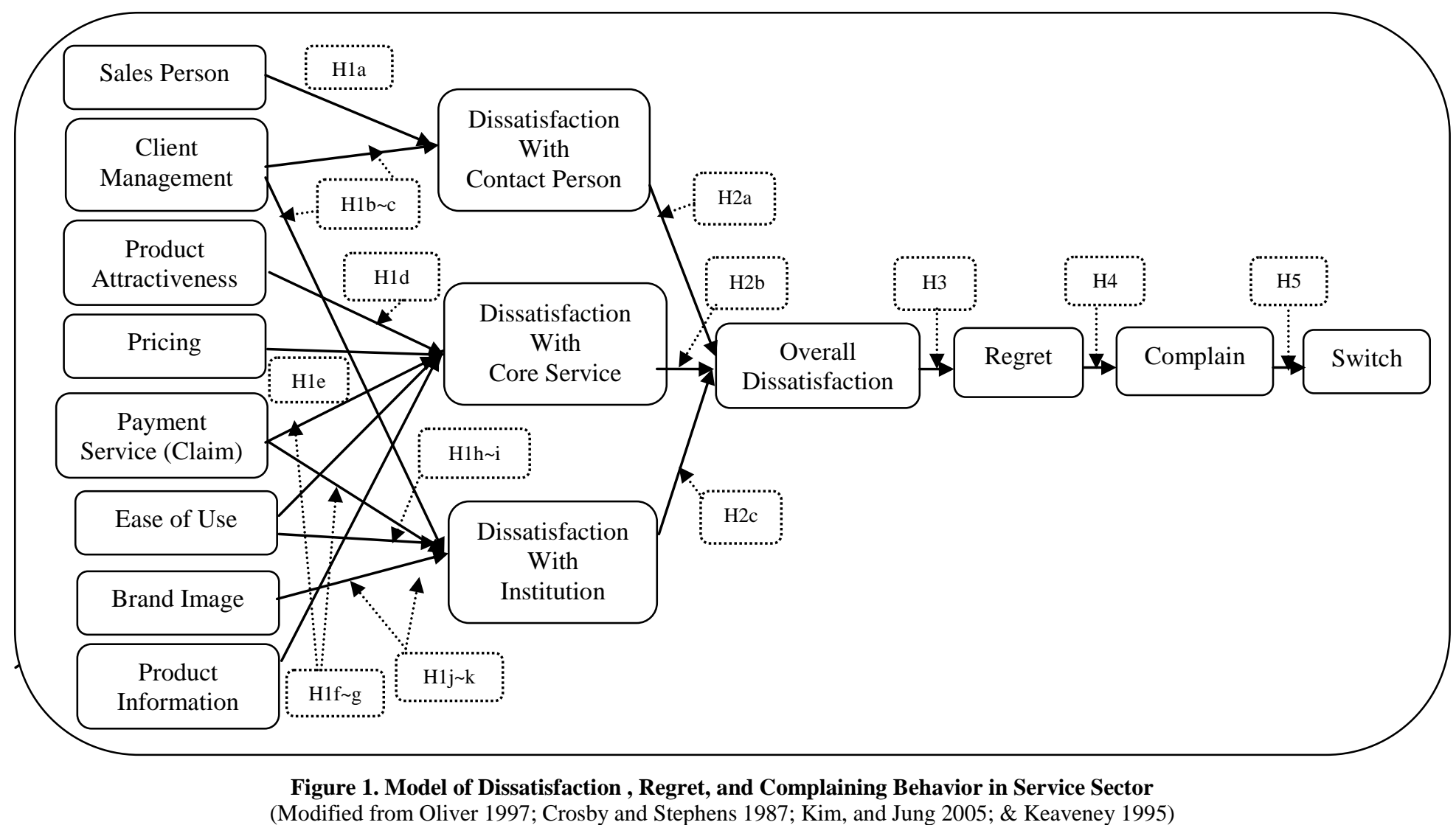


By applying the model of REM, this study addressed customer dissatisfaction, a state of cognitive or emotive discomfort caused by insufficient return relative to the resources invested (time, money, emotion, and so on) by the consumer at any stage the relationship with the seller (Fornell \& Wernerfelt, 1987), which has been the focus of much research in recent years (Yang et al., 2009). However, contrary to a popular notion, customer dissatisfaction has a positive impact in that it impels a firm to create better products and provide better services (Yang et al., 2009). At the same time, consumers are often motivated to search for new information as well as becoming willing to adopt new products and services (Yang et al. 2009). Therefore, in an era that constantly emphasizes the need for change, creativity, and innovation (Frohman, 1997), the question still arises whether consumer dissatisfaction remains a detriment for consumer innovation (Yang et al., 2009).

As Hirschman (1970) suggests, the exit-voice-loyalty (EVL) theory is mainly applicable in situations, where the consumer is dissatisfied with the seller. A review of the satisfaction/dissatisfaction literature suggests that consumers respond to dissatisfaction behavior in one of three ways: consumers could "exit" the relationship by not purchasing again, they could "voice" their complaints to management, or they could remain "loyal" by electing to repurchase at another time (Hirschman, 1970; Huefner \& Hunt, 2000). As Farrell (1983) suggested, exit and voice are active responses, whereas neglect and loyalty are passive responses. The fundamental difference between the two types of active response, exit and voice, is that exit can be destructive to an organization, whereas voice is constructive (Van Dyne \& LePine, 1998). Hirschman's EVL theory pointed out the principle of impotent conception: the voice option is the only way in which dissatisfied customers or members can react when the exit option is unavailable (Yang et al., 2009).

\section{Effects of Factors on the Service Sector}

Relationship Effects Model, as proposed by Crosby and Stephens (1987), argued that factors such as interaction and communications variables for policyholders of the service sector follow flows by examining predictors of satisfaction. Proposed variables, such as customer service failure, personal contact, and product information are used as predictors for satisfaction with contact person, satisfaction with core services, and satisfaction with institution. By applying the consequences of REM, this study also measured the effects of causes that affect dissatisfaction, regret, and complaining behavior in the service sector. This study proposed causes of effects of negative aspects of the service sector including sales person, client management, product attractiveness, pricing, payment service, ease of use, brand image, and product information. The study hypothesized how those proposed factors affect dissatisfaction with contact person, dissatisfaction with core services, and dissatisfaction with institution. Further, this study also hypothesized that dissatisfaction in these areas affects overall dissatisfaction.

H1a: As the quality of assurance on current insurance services by sales persons decreases, the level of dissatisfaction with contact person increases.

H1b c: As the quality of client management services decrease, the level of dissatisfaction with both contact person and institution increases.

H1d: As the level of product attractiveness decreases, the level of dissatisfaction with core service increases.

H1e: As the doubt of pricing increases, the level of dissatisfaction with core service increases.

H1f g: As the quality of payment services decreases, the level of dissatisfaction with both core service and institution increases.

H1h i: As the level of ease of use decreases, the level of dissatisfaction with both core service and institution increases.

H1j: As the level of a company's brand image decreases, the level of dissatisfaction with the institution increases.

H1k: As the quality of product information decreases, the level of dissatisfaction with the institution increases. 
H2a c: The higher level of dissatisfaction with each contact person, core service, and institution affects the higher level of overall dissatisfaction.

\section{Dissatisfaction and Regret}

Oliver (1997) explained dissatisfaction as the consumers' fulfillment response. A judgment that a product or service feature, or the product or service itself, provides (or is providing) a discomfort level of consumptionrelated fulfillment, including levels of under-fulfillment, also explains dissatisfaction (see also Cho, 2011). When people evaluate outcomes, they compare what they have received with what they would have received had they made a different choice (Boles and Messick 1995; Landman 1987). Conversely, if a different choice would have led to a worse outcome, people will rejoice (Tsiros and Mittal, 2000). Thus, regret (rejoicing) is the result of comparing one's outcome with a better (worse) outcome that would have occurred had a different alternative been selected (Tsiros and Mittal, 2000). Zeelenberg (1996) defined regret as "a negative, cognitively determined emotion that we experience when realizing or imaging that our present situation would have been better, had we acted differently. As an outcome of dissatisfaction, regret has been considered as a psychological construct, "what might have been and what I knew would be." (Oliver 1997). Prior studies (Bell 1982; Loomes and Sugden 1982) also stated that decision regret is a consequence of decision making under risk, and may arise when individuals appear, after the fact, to have made the wrong decision even if the decision appeared to be the right one at the time it made.

H3: The higher level of overall dissatisfaction affects the higher level of regret.

\section{Complaining \& Switching Behavior}

Prior studies (Ping 1993; Richins 1987) defined that responses to dissatisfaction as complaints (Singh and Howell 1985), negative word of mouth (Diener and Grayser 1978; Richins 1983), and brand switching (LaBarbara and Mazursky 1983). Complaints explained by a complaint process model comprised the dissatisfaction in a deficit situation (Oliver 1997). Hart, Heskett, and Sasser (1990) stated that in the context of services, "more than half" of efforts to respond to service failure actually "reinforce negative reactions" (Oliver, 1997). Customer switching behavior represents a dynamic process that develops over a particular period of time and finally results in the end of the relationship (Bejou, Palmer, 1998; Hocutt, 1998; Stewart, 1998). A study by Zikiene and Bakanauskas (2009) also indicated that when associating customer switching behavior with customer disloyalty, it is necessary to make a distinction between behavioral and attitudinal dimensions: Customer switching behavior can be directly expressed through behavioral but not attitudinal disloyalty. According to Keaveney (1995), a review of the services and products literature revealed a variety of potential, and sometimes conflicting, reasons that customers might switch services. For example, customer switching has been related to perceptions of quality in the banking industry (Rust and Zahorik 1993), overall dissatisfaction in the insurance industry (Crosby and Stephens 1987), and service encounter failures in retail stores (Kelley, Hoffman, and Davis 1993). The service literature also examined behavioral intentions variables, such as "intentions to switch" or "intentions to repatronize a service," in tests of the nomological, measurement, or predictive validity of the service quality-satisfaction model (Bitner 1990; Boulding, Kala, Staelin, and Zeithaml. 1993; Cronin and Taylor 1992). Those results suggested that satisfaction and service quality are related to service switching (Keaveney, 1995). Keaveney (1995) stated that service quality failures and dissatisfaction represent some of the reasons that customers switch services, while they do not account for them all. Bitner (1990) speculated that time or money constraints, lack of alternatives, switching costs, and habits might also affect service loyalty; Cronin and Taylor (1992) suggested that convenience, price, and availability might enhance customer satisfaction and ultimately affect behavioral intentions.

H4: As the level of regret increases, the level of complaints increases.

H5: As the level of complaints increases, the level of switching behavior increases.

\section{METHODOLOGY}

This study, first, examined customers' experiences of purchasing products and services and overall satisfaction in the online environment. This study also measured purchasing experiences of services, particularly 
insurance, in the offline environment. In order to measure the willingness to switch from offline to online purchasing, this study investigated the links among factors that affect dissatisfaction, overall dissatisfaction, regret, and complaining behavior. This study collected data via online methods, with the assistance of a well-known research firm by distributing the survey to panels that have insurance and online purchasing experiences. This study applied stratified sampling in the data collection process, based on the percentage of customers according to gender, age, education, income, field of work, and geographical location based on residency. A total of four hundred and sixteen respondents completed the survey, with a response rate of $1.4 \%$.

Multi-item scales were used to measure each of the constructs that serve as the basis for the questionnaire items. This study applied a 7 point Likert scale, with higher numbers representing higher levels of feelings, such as strongly agree (Cho, 2011). It also included several open-ended questions. The items further developed some scales taken from previous studies (Oliver, 1997; Oliver, 1980; Cho, 2011; Cho, Im, and Hiltz 2003, Blodgett, Hill, and Tax, 1997; Blodgett, Granbois, and Walters, 1993) and were modified to serve the objectives of this study. Three experts with experience in the area reviewed the survey items. After the review and a pilot study, the researchers selected approximately 67 major items to represent the major constructs, such as factors that affect dissatisfaction, overall dissatisfaction, regret, complaining behavior, and switching behavior. The applied Cronbach's alpha provided the construct reliability for multi-item scales of each construct. This study found that the Cronbach's alpha for factors that affect dissatisfaction shows as follows: i) 0.87 for sales person; ii) 0.74 for client management; iii) 0.63 for product attractiveness; iv) 0.65 for pricing; v) 0.80 for payment service; vi) 0.81 for easy to use; vii) 0.77 for brand image; and viii) 0.76 for product information. The study found a Cronbach's alpha of 0.86 for dissatisfaction, 0.70 for regret, and 0.75 for complaining behavior.

\section{RESULTS}

\section{Respondents Demographics}

Of the 416 respondents, $49.6 \%$ were female and $50.4 \%$ were male. About $22.5 \%$ were $20-29$ years old; $25.7 \%$ were $30-39$ years old; $24.9 \%$ were in their 40 s; $16.7 \%$ were in their 50 s, and $10.2 \%$ were 60 years old or older. Approximately $22.0 \%$ reported that their highest educational level as high school graduate, $12.3 \%$ had an associate's degree, $53.3 \%$ had an undergraduate degree, and $12.3 \%$ had a graduate degree. About $1.9 \%$ of respondents stated their annual incomes as less than $\$ 10,000,9.4 \%$ between $\$ 10,000$ and $\$ 20,000,17.4 \%$ between $\$ 20,000$ and $\$ 30,000,21.5 \%$ between $\$ 30,000$ and $\$ 40,000,24.5 \%$ between $\$ 40,000$ and $\$ 50,000$ and $25.7 \%$ earned more than $\$ 50,000$. About $60.7 \%$ stated they were white-collar workers, $16.5 \%$ were housewives, $10.1 \%$ were bluecollar workers, $5.6 \%$ were educators, and $4.1 \%$ were students.

\section{Hypotheses Testing}

The study validates the factors that affect dissatisfaction, including sales person, client management, product attractiveness, pricing, payment service, ease of use, brand image, and product information, dissatisfaction, regret, complaining behavior, and switching behavior. Using principal components analyses as the extraction method and Varimax rotation methods with Kaiser Normalization, the most relevant data emerged. The results of factor analyses show that items represent distinct reduced factors with Eigen values over 1.00. Table 1 shows the factor analysis results for the factors that affect dissatisfaction in the service sector. 
Table 1. Component Matrix: the Factors that Affect Dissatisfaction in the Online Service Sector

\begin{tabular}{|c|c|c|c|c|c|c|c|c|c|}
\hline \multicolumn{2}{|r|}{ Items } & \multicolumn{8}{|c|}{ Components } \\
\hline Factors & Scale Items & 1 & 2 & 3 & 4 & 5 & 6 & 7 & 8 \\
\hline $\begin{array}{l}\text { Sales Person } 1 \\
\text { Sales Person } 4 \\
\text { Sales Person } 2 \\
\text { Sales Person } 6 \\
\text { Sales Person } 5 \\
\text { Sales Person } 3\end{array}$ & $\begin{array}{l}\text { How agents are well-trained and informed is important. } \\
\text { How agents try to maximize my interests is important. } \\
\text { I think that policy's terms and condition need to be clearly explained by agents. } \\
\text { How agents are quickly responding my contact is important. } \\
\text { How agents are consistently keep a good business manner is important. } \\
\text { I expect that agents should provide personalized financial service. }\end{array}$ & $\begin{array}{l}.891 \\
.889 \\
.885 \\
.860 \\
.843 \\
.755\end{array}$ & & & & & & & \\
\hline $\begin{array}{l}\text { Client Mgmt } 6 \\
\text { Client Mgmt } 4 \\
\text { Client Mgmt } 1 \\
\text { Client Mgmt } 5\end{array}$ & $\begin{array}{l}\text { I remember that overall, customer service representatives are well trained. } \\
\text { If I get insured via online, I would get more well-personalized service. } \\
\text { I think that I can easily modify policies as my life changes when I get insured via offline } \\
\text { (e.g., easy to contact to salesperson, etc.). } \\
\text { I expect that no penalty to provisions for convertibility of products is necessary. }\end{array}$ & & $\begin{array}{l}.799 \\
.765 \\
.663 \\
.632\end{array}$ & & & & & & \\
\hline $\begin{array}{l}\text { Product Att } 3 \\
\text { Product Att } 2 \\
\end{array}$ & $\begin{array}{l}\text { How insurance service has differentiated from others by providing better valued } \\
\text { product/service is important. } \\
\text { How insurance has availability of flexible product solution is important. }\end{array}$ & & & $\begin{array}{l}.923 \\
.895 \\
\end{array}$ & & & & & \\
\hline $\begin{array}{l}\text { Pricing } 1 \\
\text { Pricing } 3 \\
\text { Pricing } 2\end{array}$ & $\begin{array}{l}\text { How firms offer proper premium price based on coverage is important. } \\
\text { When insurance companies raise the rate or premium, I think they have appropriate } \\
\text { reasons. } \\
\text { I believe how insurance companies have proper premium price based on risk rating class } \\
\text { is important. }\end{array}$ & & & & $\begin{array}{l}.863 \\
.829 \\
.776 \\
\end{array}$ & & & & \\
\hline $\begin{array}{l}\text { Payment Sys } 2 \\
\text { Payment Sys } 1 \\
\text { Payment Sys } 3\end{array}$ & $\begin{array}{l}\text { I expect that insurance has prompt claim payment. } \\
\text { I expect that insurance provides appropriate payment service as promised. } \\
\text { I expect that insurance has hassle free regarding claim payment. }\end{array}$ & & & & & $\begin{array}{l}.906 \\
.899 \\
.804\end{array}$ & & & \\
\hline $\begin{array}{l}\text { Easy To Use } 5 \\
\text { Easy To Use } 6 \\
\text { Easy To Use } 3 \\
\text { Easy To Use } 1 \\
\text { Easy To Use } 4\end{array}$ & $\begin{array}{l}\text { It is important that requests should handle promptly. } \\
\text { It is important that easy and quick contact to insurance companies whenever customers } \\
\text { need. } \\
\text { I think that the office has accessible location and flexible hours. } \\
\text { How insurance service provide simple and less time consuming procedure for purchasing } \\
\text { is important. } \\
\text { I expect that insurance company has adequate number of branches. }\end{array}$ & & & & & & $\begin{array}{l}.887 \\
.879 \\
.820 \\
.765 \\
.742 \\
\end{array}$ & & \\
\hline $\begin{array}{l}\text { Brand Image } 5 \\
\text { Brand Image } 1 \\
\text { Brand Image } 4\end{array}$ & $\begin{array}{l}\text { I expect that insurance company must possess good certification and credentials. } \\
\text { I believe how much the insurance company is financially stable company is important. } \\
\text { I believe that insurance company must have good reputation. }\end{array}$ & & & & & & & $\begin{array}{l}.906 \\
.887 \\
.845\end{array}$ & \\
\hline $\begin{array}{l}\text { Product Info } 1 \\
\text { Product Info } 4 \\
\end{array}$ & $\begin{array}{l}\text { I believe how much receiving information from sales person about insurance services is } \\
\text { important. } \\
\text { It is important that getting information reduce my uncertainty. }\end{array}$ & & & & & & & & $\begin{array}{r}.903 \\
.880 \\
\end{array}$ \\
\hline
\end{tabular}


Further, this study applied analyses, such as regression analysis and the analysis of variance (ANOVA). Table 2 provides the results of the regression analyses using factor scores for the effects of factors that affect dissatisfaction with contact person, institution, and core service. Overall, the results of the ANOVA in the case of impacts of sales person on dissatisfaction with contact person find the models significant at the .01 level with $F=$ 184.169 ( $r$-square $=.309)$; in the case of impacts of client management on dissatisfaction with contact person find the models significant at the .01 level with $F=114.124$ ( $r$-square $=.217)$; in the case of impacts of client management to dissatisfaction with institution find the models significant at the .01 level with $F=57.290$ ( $r$-square $=.122)$; in the case of impacts of product attractiveness on dissatisfaction with core service find the models significant at the .01 level with $F=162.662(r$-square $=.284)$; in the case of impacts of pricing factor on dissatisfaction with core service find the models significant at the .01 level with $F=181.541$ ( $r$-square $=.306$ ), in the case of impacts of payment service on dissatisfaction with core service find the models significant at the .01 level with $F=71.517$ ( $r$-square $=.148$ ); in the case of impacts of payment service on dissatisfaction with institution find the models significant at the .01 level with $F=33.749$ ( $r$-square $=.076$ ); in the case of impacts of easy to use factor on dissatisfaction with core service find the models significant at the .01 level with $F=240.022$ ( $r$-square $=$ .369); in the case of impacts of the ease of use factor on dissatisfaction with institution find the models significant at the .01 level with $F=165.144$ ( $r$-square $=.287)$; in the case of impacts of brand image on dissatisfaction with institution find the models significant at the .01 level with $F=128.710(r$-square $=.238)$; and in the case of impacts of product information on dissatisfaction with institution find the models significant at the .01 level with $F=$ 119.251 ( $r$-square $=.225)$. The results of regression analyses demonstrate that effects of factors on dissatisfaction with contact person, institution, and core service are all accepted $(\mathrm{H} 1 \mathrm{a} \sim \mathrm{H} 1 \mathrm{k})$.

Table 2. Summary of the Effects of Factors to Dissatisfaction in the Online Service Environment

\begin{tabular}{|l|l|}
\hline \multicolumn{1}{|c|}{ Variable (Independent $->$ dependent) } & Standardized Coefficient $(\boldsymbol{t}$-value-Sig) \\
\hline Sales Person-> Dissatisfaction with Contact Person (H1a) & $0.556(13.571 * * *)$ \\
\hline Client Management -> Dissatisfaction with Contact Person (H1b) & $0.466\left(10.683^{* * *)}\right.$ \\
\hline Client Management -> Dissatisfaction with Institution (H1c) & $0.350(7.569 * * *)$ \\
\hline Product Attractiveness -> Dissatisfaction with Core Service (H1d) & $0.532(12.754 * *)$ \\
\hline Pricing -> Dissatisfaction with Core Service (H1e) & $0.554(13.474 * * *)$ \\
\hline Payment Service (Claim) -> Dissatisfaction with Core Service (H1f) & $0.385(8.457 * * *)$ \\
\hline Payment Service (Claim) -> Dissatisfaction with Institution (H1g) & $0.275(5.809 * * *)$ \\
\hline Easy to Use -> Dissatisfaction with Core Service (H1h) & $0.607\left(15.493^{* * *)}\right.$ \\
\hline Easy to Use -> Dissatisfaction with Institution (H1i) & $0.535\left(12.851^{* * *}\right)$ \\
\hline Brand Image -> Dissatisfaction with Institution (H1j) & $0.488\left(11.345^{* * *}\right)$ \\
\hline Product Information -> Dissatisfaction with Institution (H1k) & $0.474\left(10.920^{* * *)}\right.$ \\
\hline
\end{tabular}

*** Significant at 0.01 level (2-tailed).

This study also applied regression analysis and the analysis of variance (ANOVA) for the relationships of impacts of dissatisfaction with contact person, institution, and core service on overall dissatisfaction, overall dissatisfaction to regret, regret to complaining behavior, and complaining behavior to switching behavior (table 3). Table 3 provides the results of the regression analyses. Overall, the results of the ANOVA in the case of impacts of dissatisfaction with contact person on overall dissatisfaction find the models significant at the .01 level with $F=$ 11.296 ( $r$-square $=.027)$; in the case of impacts of dissatisfaction with core service on overall dissatisfaction find the models significant at the .01 level with $F=11.074$ ( $r$-square $=.026)$; in the case of impacts of dissatisfaction with institution on overall dissatisfaction find the models significant at the .10 level with $F=2.745$ ( $r$-square $=$ $.042)$; in the case of overall dissatisfaction on regret find the models significant at the .01 level with $F=26.311(r$ square $=.060)$; in the case of regret on complaining behavior find the models significant at the .01 level with $F=$ 61.447 ( $r$-square $=.130)$; and in the case of impacts of complaints ono switching behavior find the models significant at the .01 level with $F=199.568$ ( $r$-square $=.327)$. 
Table 3. Summary of the Effects of Dissatisfaction, Regret, Complain, and Switching Behavior in the Online Service Environment

\begin{tabular}{|l|c|}
\hline \multicolumn{1}{|c|}{ Variable (Independent -> dependent) } & Standardized Coefficient (t-value-Sig) \\
\hline Dissatisfaction with Contact Person -> Overall Dissatisfaction (H2a) & $0.164(3.361 * * *)$ \\
\hline Dissatisfaction with Core Service -> Overall Dissatisfaction (H2b) & $0.162\left(3.328^{* * *)}\right.$ \\
\hline Dissatisfaction with Institution -> Overall Dissatisfaction (H2c) & $0.081\left(1.657^{* *)}\right.$ \\
\hline Overall Dissatisfaction -> Regret (H3) & $0.245(5.129 * * *)$ \\
\hline Regret -> Complain (H4) & $0.361\left(7.839^{* * *)}\right.$ \\
\hline Complain -> Switching (H5) & $0.572(14.127 * * *)$ \\
\hline$* * *$ Significant at 0.01 (H)
\end{tabular}

*** Significant at 0.01 level (2-tailed); ** Significant at 0.10 level (2-tailed).

\section{CONCLUSION}

The purpose of this research was to explore how willing customers are to adopt the service sector in the online environment. In order to examine customer adoption of the service sector from offline to online, this study investigated the relationships of negative factors that impact of dissatisfaction, overall dissatisfaction, regret, complaining, and switching behavior in the service sector in the virtualized environment. By considering the factors that affect customer dissatisfaction with the service sectors, particularly with insurance sector, this study addressed how customers are willing to switch to the virtualized environment. This study identified significant relationships such as i) how proposed factors affect dissatisfaction with three categories, such as contact person, institution, and core service; ii) how the dissatisfaction with contact person, institution, and core service affects the overall dissatisfaction; iii) how the overall dissatisfaction affects the regret; iv) how the regret affects complaining behavior; and v) how complaining behavior affects switching behavior.

Theoretically, this study contributes to the development of the relationships among the negative sides of satisfaction including dissatisfaction, regret, complaining and switching behavior in the virtualized environment. Various researchers have examined issues of satisfaction in the virtualized environment, but few studies have investigated issues of dissatisfaction and relationships to the complaining and switching behavior (Cho, 2011). By applying the theoretical insights of Hirschman's exit, voice, and loyalty, this study proves the options for customers of deteriorating service: leave the relationship (exit) or communicate their displeasure to the institution (voice).

Managerially, this study provides implications and suggestions to e-Commerce Customer Relationship Management (eCCRM) by proposing what lead customers to switch channels from offline and online, particularly with the purchase of the service. A study by Gupta, Su, and Walter (2004) stated that it is critically important for practitioners and academics to understand consumer channel-switching behavior (from offline to online) and identify the factors that influence it. Customers' behavior in relation to the product, including purchase decision gradually changed from offline to online with the development of e-commerce, while customers' actual behavior (e.g., purchasing behavior) on service remained in the offline with some service sector. By considering the development of internet and advanced services, this study posits that an examination of the negative sides of satisfaction will encourage customers to switch to online. Further, this study provided implications and suggestions for e-Commerce Customer Relationship Management (eCCRM) by identifying factors that affect dissatisfaction, and how dissatisfaction affects regret, complaints, and willingness to switch the behavior.

The study has several implications. This study has explored relationships on the negative sides of satisfaction that also lead to switching the behavior of service sector in the virtualized environment. Although this study applies multivariate statistics, further studies might consider the measurement of a cause-and-effect relationship. Finally, further research might consider applications to other environments, such as crosscultures/countries, for generalization.

\section{ACKNOWLEDGEMENT}

The author is grateful for the financial support from the KDI School of Public Policy and Management. 


\section{AUTHOR INFORMATION}

Yoon C. Cho, Associate Professor, KDI School of Public Policy and Management. Send correspondence to Prof. Yoon C. Cho, KDI School of Public Policy and Management, 87 Hoegiro, Dongdaemun Gu, Seoul, Korea, Tel: +82-2-3299-1087. E-mail: ycho@kdischool.ac.kr; yoonji22e@gmail.com (Corresponding author)

Juyeon Song, Georgia Institute of Technology, received master degree from the KDI School of Public Policy and Management. E-mail: juyeon_song@yahoo.com

\section{REFERENCES}

1. Ahn, Cheonkyoung, and Ki, Seungdo (2007), "Analysis of the U.S. and UK Insurance Market," Insurance Business Report, 23 (July).

2. Bejou, D. and Palmer A. (1998), "Services Failure and Loyalty: An Exploratory Empirical Study of Airline Customers," Journal of Services Marketing, 12, 1. pp.7-22.

3. Bell, David E. (1982), "Regret in Decision Making under Uncertainty," Operations Research, 30 (September/October), pp.961-981.

4. Bitner, Mary Jo (1990), "Evaluating Service Encounters: The Effect of Physical Surroundings and Employee Responses," Journal of Marketing, 54 (April), pp.69-82.

5. Boles, Terry L. and David M. Messick (1995), "A Reverse Outcome Bias: The Influence of Multiple Reference Points on the Evaluation of Outcomes and Decisions," Organizational Behavior and Human Decision Processes, 61 (March), pp.262-275.

6. Boulding, William, Kalra, Ajay, Staelin, Richard, and Zeithaml, Valarie A. (1993), “A Dynamic Process Model of Service Quality; from Expectations to Behavioral Intentions," Journal of Marketing Research, 30 (February), pp.7-27.

7. Chan, Thomas, S. F. (1998), "Consumer complaints, Racial Discrimination, and Distribution Channels in Private Passenger Auto Insurance," Journal of Insurance Regulation, Fall, 17, 1, pp.24-41.

8. Chen, Lei-Da, and Tan, Justin (2004), "Technology Adaptation in E-commerce: Key Determinants of Virtual Stores Acceptance," European Management Journal, 22, 1 (February), pp. 74-86.

9. Chiu, Mei-Ching and Shin, Yong-Ming (2009), "The Determinants of Online Insurance Behavior: An Empirical Study in Taiwan,” Decision Sciences Institute, Distinguished Track Papers for E-Commerce.

10. Cho, Y., Im, I., Hiltz, S. \& Fjermestad, J. (2001), The Effects of Post-Purchase Evaluation Factors on Online vs. Offline Customer Complaining Behavior: Implications for Customer Loyalty, Advances in Consumer Research (ACR), 29, pp.318-326.

11. Cho, Yoon C. (2011), "Analysis of Customer Dissatisfaction toward Perishable Grocery Goods," Journal of Business Research, 64, pp.1245-1250.

12. Cho, Yoon C. (2012), "Exploring Relationship among Customer Dissatisfaction, Complaints, and Loyalty in the Virtualized Environment: Roles of Advanced Services," Working Paper.

13. Cronin, Joseph J., Jr. and Taylor, Steven A., (1992) "Measuring Service Quality: A Reexamination and Extension," Journal of Marketing, 56, pp.55-68.

14. Crosby, Lawrence A., and Stephens, Nancy (1987), "Effects of Relationship Marketing on Satisfaction, Retention, and Prices in the Life Insurance Industry," Journal of Marketing Research, 24, 4(November), pp.404-411.

15. Crosby, Lawrence A., Evans, Kenneth R., and Cowles, Deborah (1990), "Relationship Quality in Service Selling: An Interpersonal Influence Perspective," Journal of Marketing, 54 (July), pp.68-81.

16. Diener, B. J. and Grayser, S. A. (1978), “Consumer Views of Redress Needs," Journal of Marketing, 42 (October), pp.21-27.

17. Durvasula, Srinivas, Lobo, Antonio C., Lysonski, Steven, and Mehta, Subhash C. (2005), "Finding the Sweet Spot: A Two Industry Study Using the Zone of Tolerance to Identify Determinant Service Quality Attributes," Journal of Financial Services Marketing, Vol.10, 3, pp.244-259.

18. Farrell, D. (1983), "Exit, Voice, Loyalty, and Neglect as Responses to Job Dissatisfaction: A Multidimensional Scaling Study," Academy of Management Journal, 26 (4), pp.596-607.

19. Figueiredo, John M. de (2000), "Finding Sustainable Profitability in Electronic Commerce," Sloan Management Review, Summer. 
20. Fornell, C. \& Wernerfelt, B. (1987). Defensive marketing strategy by customer complaint management: A theoretical analysis. Journal of Marketing Research, 24(4), pp.337-346.

21. Frohman, A. L. (1997). Igniting organizational change from below: The power of personal initiative. Organizational Dynamics, 25(3), pp.39-53.

22. Gehrt, K. C. and Yan, R. (2004). Situational, Consumer, and Retailer Factors affecting Internet, Catalog, and Store Shopping. International Journal of Retail \& Distribution Management, 32(1), pp.5-18.

23. Gehrt, K.C., Ingram, T. N., and Howe, V. (1991). Non-store versus Store Retailing: A Situationally Based Market Structure Assessment. Journal of Direct Marketing, 5(2), pp.44-53.

24. Gupta, Alok, Su, Bo-Chiuan, and Walter, Zhiping (2004), "An Empirical Study of Consumer Switching from Traditional to Electronic Channels: A Purchase-Decision Process Perspective," International Journal of Electronic Commerce, 8, 3 (Spring), pp.131-161.

25. Hart, Christopher, Hestkett, James L., and Sasser, W. Earl Jr. (1990), "The Profitable Art of Service Recovery,” Harvard Business Review, 68 (July-August), pp.148-156.

26. Hirschman, A. O. (1970). Exit, voice and loyalty. Cambridge: Harvard University Press.

27. Hocutt, M. A. (1998), "Relationship Dissolution Model: Antecedents of Relationship Commitment and the Likelihood of Dissolving a Relationship," International Journal of Service Industry Marketing, 9, 2. pp.189-200.

28. Hoffman, Donna. L. and Novak, Thomas P. (1996), "Marketing in Hypermedia Computer-Mediated Environments: Conceptual Foundations," Journal of Marketing, 60, pp.50-68.

29. Huefner, J. C. \& Hunt, H. K. (2000). Consumer retaliation as a response to dissatisfaction. Journal of Consumer Satisfaction, Dissatisfaction and Complaining Behaviour, 13, pp. 61-82.

30. Inman, Jeffrey J. and Zeelenberg, Marcel (2002), "Regret in Repeat Purchase versus Switching Decisions: The Attenuating Role of Decision Justifiability," Journal of Consumer Research, 29 (June), pp.116-128.

31. Johnston-O'Connor, Elizabeth, O'Connor, Robert J., and Zultowski, Walter H. (1984), "The Personal Selling Process in the Life Insurance Industry," in Personal Selling: Theory, Research and Practice, J. Jacoby and C. S. Craig, eds. Lexington, MA: Lexington Books, pp.205-22.

32. Keaveney, Susan M. (1995), "Customer Switching Behavior in Service Industries: An Exploratory Study," Journal of Marketing, 59 (April), pp.71-82.

33. Kelley, Scott W., Hoffman, K. Douglas, and Davis, Mark A. (1993), “A Typology of Retail Failures and Recoveries," Journal of Retailing, 69 (Winter), pp.429-52.

34. Kim, Yongkwang, and Jung, Hongjoo, "An Empirical Study on the Conceptualization of the Life Insurance Service Quality," Korean Insurance Academic Society Publication, 2005, 70, pp.1-40.

35. LaBarbara, P. A. and Mazursky, D. (1983), "A Longitudinal Assessment of Consumer Satisfaction/Dissatisfaction: The Dynamic Aspect of the Cognitive Process," Journal of Marketing Research, 20 (November), pp.393-404.

36. Landman, Janet (1987), "Regret: A Theoretical and Conceptual Analysis," Journal of Theory of Social Behavior, 17 (June), pp.135-160.

37. Loomes, Graham and Robert Sugden (1982), "Regret Theory: An Alternative Theory of Rational Choice under Uncertainty," Economics Journal, 92 (December), pp.805-824.

38. Lynch, Michael P. and Mackay, Rebert J. (1985), Life Insurance Products and Consumer Information, FTC Staff Report. Washington, DC: U.S. Government Printing Office, pp.280-300.

39. Mohammed, R.A., Fisher, R.J., Jaworski, B.J., and Cahill, A.M. (2002), "Internet Marketing: building Advantage in a Networked Economy," McGraw-Hill.

40. Oliver, R. L. (1997), Satisfaction: A Behavioral Perspective on the Consumer, Irwin McGraw-Hill.

41. Palmer, J. W. (1997), "Electronic Commerce in Retailing: Differences across Retail Format," The information Society, 13, 75-91.

42. Peppard, Joe and Rylander, Anna, "Products and services in cyberspace," International Journal of Information Management 25, 2005, pp. 335-345.

43. Ping, Robert, A. (1993), "The Effects of Satisfaction and Structural Constraints on Retailer Existing, Voice, Loyalty, Opportunism, and Neglect," Journal of Retailing, 69, 3, Fall, pp.320-352.

44. Richins, M. L. (1983), "Negative Word of Mouth by Dissatisfied Consumers," Journal of Marketing, 47, Winter, pp.68-78.

45. Richins, M. L. (1987), “A Multivariate Analysis of Reponses to Dissatisfaction,” Journal of the Academy of Marketing Science, 15, Fall, pp.24-31. 
46. Rust, R. T. and Zahoric, A. J. (1993), "Customer Satisfaction, Customer Retention, and Market Share,” Journal of Retailing, 69, 2. Pp.193-216.

47. Singh, J. and Howell, R. D. (1985), “Consumer Complaining Behavior: A Review and Prospectus,” In Consumer Satisfaction, Dissatisfaction, and Complaining Behavior, H. K. Hunt, R. L. Day, eds. Bloomington, Indiana University.

48. Steuer, Jonathan (1992), “Defining Virtual Reality: Dimensions Determining Telepresence,” Journal of Communication, (Autumn), pp.73-93.

49. Stewart, K. (1998), “The Customer Exit Process - a Review and Research Agenda,” Journal of Marketing Management, 14. pp.235-250.

50. Sugden, Robert (1985), "Regret, Recrimination, and Rationality,” Theory and Decision, 19 (July), pp.7799.

51. Tsiros, Michael and Vikas Mittal (2000), "Regret: A Model of Its Antecedents and Consequences in Consumer Decision Making,” Journal of Consumer Research, 26 (March), pp.401-417.

52. Upah, Gregory D. (1980), "Mass Marketing in Service Retailing: A Review and Synthesis of Major Methods, ”Journal of Retailing, 56 (Fall), pp.59-76.

53. Van Dyne, L. and LePine, J. A. (1998) "Helping and Voice Extra-role Behaviors: Evidence of Construct and Predictive Validity," Academy of Management Journal, pp.108-119.

54. Yang, Szu-Chi, Tu, Chiayu and Yang, Suechin (2009), "Exploring the Solution-the contextual effect in consumer dissatisfaction and innovativeness in financial service companies," The Service Industries Journal, 29, 4 (April), pp.557-568.

55. Yi, Youjae. (1990). A Critical Review of Consumer Satisfaction. In Valarie A. Zeithaml (ed.), Review of Marketing, American Marketing Association, Chicago, pp.68-123.

56. Zeelenberg, M. (1996), "On the importance of what might have been: Psychological perspectives on regret and decision making," Ph.D. dissertation, Faculty of Psychology, University of Amsterdam.

57. Zeithaml, Valarie A., Parasuraman, A., and Berry, Leonard L. (1985), "Problems and Strategies in Services Marketing," Journal of Marketing, 49 (Spring), pp.33-46.

58. Zikiene, Kristina (2009), "Research of Factors Influencing Loyal Customer Switching Behavior,” Journal of Organization Vadyba, 52, pp.153-170.

\section{Other Resources}

Insurance Research Council Survey (2009). 


\section{NOTES}

